DOI: https://doi.org/10.24297/jssr.v14i0.8470

\title{
The Growing Power Struggle in Indian Ocean Region: Security Road Map for Bangladesh
}

\author{
Abu Sadat Mahmud Safeer Chowdhury, S. Inderjit, Tharishini Krishnan \\ National Defence University Malaysia \\ safeermahmud82@gmail.com, tharishini@upnm.edu.my,sinder1866@yahoo.com
}

\begin{abstract}
The Indian Ocean Region (IOR) is rising significantly as the centre stage for world politics in current century. Due to the geostrategic and economic importance, the region has created conflicts in strategic interest leading to power confrontation among regional and extra regional powers resulting in security threats for small littorals like Bangladesh. Some of the threats are influential attachments of the powerful states in foreign, trade, economy and defence sectors, poor regional security architecture and increase of non-traditional security threats. Analysing the issues reveals that, Bangladesh can navigate these challenges by playing strategic hedging, pursuing multilateralism, recalibrating trade and economic engagements, and comprehensive drive by government agencies to deal non-traditional security threats.
\end{abstract}

Keyword: Bangladesh, Indian Ocean, Maritime Security.

\section{INTRODUCTION}

The Indian Ocean Region (IOR) - a great sea area where many civilizations have mingled for hundreds of years is undeniably becoming a strategic junction of the current world affairs. In fact, its geostrategic and economic importance is much more pronounced today than what it was before. The growing significance of the Sea Lanes of Communication (SLOC), chokepoints, reliance on hydrocarbon resources, growing power of India and China as well as chaotic security environment is being thought an area of vital geostrategic significance. On the other hand, interest of big powers and other extra regional powers and the proliferation of non-traditional threats by non-state actors are influencing the regional affairs increasingly (Michel \& Sticklor, 2012). This is making the littoral countries much uncomfortable in adjusting their positions under such scenarios of power struggle. In this connection, the national interests and security of a small state like Bangladesh is becoming vulnerable due to the volatility of the situation.

Bangladesh is situated geopolitically in a vital spot bridging the gap between South and South-East Asia (SEA). Recently, peaceful settlement of maritime dispute with both India and Myanmar at the Permanent Court of Arbitration (PCA) in Hague and International Tribunal for the Law of the Sea (ITLOS) in Hamburg has given her tremendous access to explore to the seas (Alam I. , 2014). At present, more than 90 per cent of foreign trade is carried over through the sea routes (Siddique, 2015). Her economic security is mostly dependent on the uninterrupted supply of goods over the Indian Ocean and Bay of Bengal. Having much of sea dependency, Bangladesh has genuine concern over the ominous sign of power struggle in IOR. Due to the power struggle, there is a reasonable probability that Bangladesh might be pawn of regional dominance and being drawn into the conflict of big powers. Playing any wrong card to any of the big players might severely affect the national security and overall interest of the country. As a littoral state of IOR, finding a security road map for Bangladesh is important. In this regard, the study will identify the security concerns for Bangladesh in IOR. The paper will then suggest some policy options that will guard her national security before drawing conclusion.

\section{SECURITY CONCERNS FOR BANGLADESH}

The dynamics of power struggle between major powers such as India, China and the United States (US) in IOR has indirect implication towards Bangladesh. For India, IOR holds special importance as she is located at the 
centre of the ocean. In this regard, India launched 'Act East Policy' (AEP) focusing on increase trade, economic and security ties with the IOR littorals including the Association of South East Asian Nations (ASEAN) (Rajagopalan, 2018). India is exerting more leadership roles in multilateral institutions such as Indian Ocean Rim Associations (IORA) which emphasizes on maritime security, culture, trade, and governance. Another naval forum named Indian Ocean Naval Symposium (IONS) where India has thrown weight to increase cooperation (Jaysankar, 2016). India is conducting sea exercises in IOR for example Ex MILAN and Ex MALABAR that specifically excludes China. Such drills create a wider belief that they target against China (Parameswaran, The Diplomat, 2018). Most importantly, India is growing her naval potency at accelerated rate. Simultaneously, she is doing enough collaboration with Russia and France in defence field for gaining more self sufficiency (Hafeez, 2017). All such developments have led to think about India's intention of how she wants to play in the power confrontation game (Brewster, The Diplomat, 2018).

While India is trying to establish dominance in the region, China remains concerned to guard her security. This has motivated her to grow military and commercial footprint in the IOR. She thereby embarked on an agenda known as Belt and Road Initiative (BRI) lending trillions of dollars to construct infrastructures for commercial use which could be later leveraged for military (Mukherjee, 2018).

There has been stark criticism calling China's BRI project as 'Debt trap'. For example, 'Hambantota Deep Sea Port' in Sri Lanka was a \$ 1.5 billion project which was launched in 2008 . The port was unable to gear much revenue and government found unable to repay the debts. Thereby, she was forced to lend Hambantota for 99 years as lease to China (Yamada \& Palma, 2018). Such example indicates China's policy of coercing nations with struggling economies to cede control over their strategically important locations (Stashwick, 2018). In this regard, Bangladesh's case is no different. So far, some of the construction project started and some in the preparatory phase. Although such investments have tangible benefits, but there is always risk of running into debt trap.

Similarly, the spillover effect of 'Trade War' is marginally felt as because the main export product 'Ready Made Garments (RMG)' is yet to fall a victim to this war. But there are skeptics, what if US imposes blanket tariff on all RMG exports (Ahasan, 2018)? Such actions will be devastating to Bangladesh's economy. Then, there is a very large trade deficit in export vs import with both China and India (shown in following graph). Therefore, it seems that there are potential risks for Bangladesh in trade and economic engagements with major powers. Meanwhile, the Chinese leadership pledged to turn their military into world fighting force by 2050 .

Her Navy is taking up increasingly prominent role to secure South China Sea (SCS) by challenging the United States (US), and defend vital seaplanes across the IOR (Reuters, 2018). Therefore, all such activities are clear indication of China's rise to challenge US hegemony and transcend as the most important player in the IOR. It is widely accepted today in US that China is going to pose a long-term strategic challenge to them. In fact, over the last few years, the rate of Chinese economic growth had been so miraculous that Chinese Gross Domestic Producr (GDP) is likely to overtake US by 2029. Against this backdrop, USA has embarked on a strategy called 'Containment' ${ }^{1}$ to contain the economic and political ascendency of China which officially they do not acknowledge (Hemmings, 2018). Then in March 2018, US initiated 'Trade War' against China with the most recent imposing 10\% tariffs on $\$ 200$ billion worth of Chinese goods. China almost immediately retaliated with similar counter measures (Kao, Crooks, \& Pong, 2018). Such measures by USA is being viewed as protectionism approach and are likely to have damaging consequence to those nations who are dependent on those two nations for exports and imports (Yueh, 2018).

For US, their strategic interest is mainly based on two reasons. Firstly, the geo strategic setting of Bangladesh sitting on the apex of Bay of Bengal, and secondly, possibility of rise of religious extremism. For the first case, the location setting has already attracted US to establish a military foothold on her shores. This is a part of their

\footnotetext{
${ }^{1}$ The strategy is a Cold War concept by US which was articulated to contain Soviet influence and ideology from spreading or globalize.
} 
overall strategy to check China's maritime ascendency (Arman, 2015). There are concerns in agreeing to such proposal as it risks her relation with other regional powers. Regarding the second case, the terrorist attack in Holy Artisan Bakery in July 2016, that saw 29 killed, brought the country under US's attention. The risk is that, any reoccurrence of such incident is going tarnish the image and affect diplomatically, economically and socially.

On the other hand, some of the regional organizations in the IOR have become defunct or not been able to deliver its expected promises. For example, SAARC (South Asian Association for Regional Cooperation) was one of the most important regional organizations that connected the member of South Asia. It was established in 1980 with a view to focus on socio-economic development and regional integration. However, the organization has failed to live up to its mandate due to Indo-Pak rivalry (Falak, 2017). Similarly, IORA (Indian Ocean Rim Association) is criticized as low-key body and yet to transform into a dynamic regional organization (Singh, 2017). In security front, IONS (Indian Ocean Naval Symposium) was established recently in 2008 to promote maritime security in the IOR and is yet to gear up into an effective regional platform.

Finally, IOR is marked by the increased presence of non-traditional security threats where Bangladesh is very much affected. To counter the non-state actors, one of the biggest problems is the lack of resources, men and coordination amongst various stake holders. The poor socio-economic condition has created opportunities for the people to indulge into illegal activities. Meanwhile, Bangladesh is a highly disaster prone country affected by regular cyclones, flood, etc. Although government response mechanism is in place but this is still a major cause for disrupting economic growth as almost every year the country has to face such disasters.

\section{POLICY OPTIONS FOR BANGLADESH}

\section{Strategic Hedging}

Many Realist scholars have identified 'Strategic Hedging' as a viable strategy for the smaller states to counter major powers instead of traditional 'Bandwagoning' or 'Balancing'. (Lee J. Y., 2017). The strategy aims no particular policy i.e. bandwagoning or balancing and seeks to offset the threats without confronting any stronger powers. For Bangladesh's case, she has to take into confidence all the major powers, therefore, should not declare her foreign policy against any major power. Thereby, she may adopt strategic hedging. For example, through hedging she may continue participate in regional security cooperation without challenging India or US's authority while simultaneously maintain economic and political ties with China. Again, she may continue to pursue military cooperation with China while engaging in social/cultural exchange and trade with her stronger neighbours to offset any potential future conflict. To explain it simply, it is about not putting all the fruits in the same basket. Such strategy in foreign affairs will allow a niche to secure her interest in this volatile environment of IOR.

\section{Addressing Security Dilemma}

Nuclear arms race and military modernization among the neighbours has created substantial 'Security Dilemma' for Bangladesh. To overcome that Bangladesh needs to develop an effective military capability through continued modernization of its armed forces. The 'National Defence Policy 2018' suggests for effect-based modernization focusing on tooth-to-tail ratio and balance between quality and quantity where emphasis to be given on Research and Development to acquire indigenous capability ${ }^{2}$. In this context, the government has taken military modernization drive by introducing "Forces Goal 2030" that prescribes acquisition modern military hardware to support the said the modernization (Mushtaq, The Diplomat, 2018). However, due small economic base, Bangladesh cannot have a large standing armed force; it should, therefore, have a reasonable sized military with a large reserve from population. The military should be equipped and trained with state-of-the-art

\footnotetext{
2 The "National Defence Policy 2018" is policy document approved by the Cabinet recently but yet to be published as white paper to the public (Bhattacharjee, 2018).
} 
platforms and equipment while the reservists will support 'People's War' concept that will dissuade any of the big powers from using military force against Bangladesh. ${ }^{3}$

\section{Cultivating Regionalism and Multilateralism}

Regionalism serves the interest of small states in particular as they provide security compared to bilateral relations where difference in power/influence are more pronounced. (Baylis, Smith, \& Owens, 2017). As discussed previously, the regional mechanism such as SAARC could not flourish. Therefore, to move forward experts have opined for 'SAARC minus one' i.e. to bypass Pakistan and maintain sub regional groupings (Miller \& Gopalaswamy, 2016). There may be a question as to why exclude only Pakistan whereas India had significant contribution for SAARC's failure. The answer for Bangladesh is she has to play Realpolitik. ${ }^{4}$ This is because India as the next neighbor has far more stake in country's foreign policy than Pakistan who is a distant relative. Therefore, finding the best alternative to SAARC and move forward with India and other sub regional groupings may be the best option for Bangladesh. Moving on to multilateralism, Bangladesh's overall national interests can be better served by its active involvement in multinational institutions like UN, NAM, G-77, Commonwealth, etc. It should also try to establish meaningful engagement with ASEAN and African Union that has stake in the IOR.

\section{Recalibrating Economic Engagements and Infrastructure Projects}

It was observed that, China's BRI has led some nations to fall to debt trap. This has made other countries alerted about the flipside of the BRI strategy. In this regard, Bangladesh's case is no different. Chinese BRI projects undergoing are likely to have damaging effect on the economy if the contracts are agreed similar to Hambantota project. Similarly, there are many projects funded by India for infrastructural and social sector development. Therefore, such contracts from India and China need a thorough review so that they do not create negative consequences. Such investments should be always welcomed, as long as they are aligned to the national interest of Bangladesh. Japan's condition for interest rates and repayment schedule are much easier than both India and China. Therefore, economic ties with Japan will likely to have strategic benefits against the shortfall experiences with China and India.

\section{Dealing Non-Traditional Threats}

The presence of non-traditional security threats demands urgent need to craft strategies for Bangladesh. The most important thing is to connect with the people and bring up the lifestyle of the people so that they do not dive into illegal activities. The law enforcement agencies need to be tailored suitably for carrying out operations against non-state actors. Then on regional level, Bangladesh should arrange mutually agreed system through joint enforcement measures to deal with the transnational threats. Coming to the disaster issue in IOR, Bangladesh is way ahead in handling the natural disasters such as cyclone and flood. However, earthquake related disaster management still needs attention where the best practices of international standard need to be incorporated. Again, as one of the victims, Bangladesh should take the leading role against the adverse effects of global warming and climate change in the region.

Moving on to terrorism, it is observed that, any reoccurrence of terrorist incident like Holy Artisan (discussed previously) will tarnish the image diplomatically and socially. To tackle the issue the government has so far carried several successful security operations. However, experts opined that kinetic efforts can only lead to reprisal of terrorist or worse. Thereby, it is important to focus on non-kinetic efforts to address the root cause of terrorism (Baylis, Smith, \& Owens, 2017). Similarly, it is identified that correct education of Islam, improvement of socio-economic condition, address the grievances of deprived populations and isolate the terrorists from

\footnotetext{
${ }^{3}$ The National Defence Policy explains People's War. The concept is to maintain the support of the population and draw the enemy deep into the interior where the population will bleed them dry through guerrilla warfare.

${ }^{4}$ A system of politics that is based on pragmatism or practical situation rather than ideological and moral consideration. The term was coined by German writer Ludwig von Rochau in $19^{\text {th }}$ century.
} 
means of support can eradicate the possibility of terrorism. ${ }^{5}$ Therefore, Bangladesh government should focus more on those non-military efforts, besides carrying out security operations to neutralize the terrorists.

\section{CONCLUSION}

The study seeks to identify the security concerns for Bangladesh in IOR and suggest some policy options that will guard her national security. In general, the paper observed interesting triangular relations among IndiaChina-US. Here, just as China views US as a hegemonic power with its 'Containment' strategy, India sees China also as expansionist and another hegemon in the region. Other players such as Saudi Arabia, Japan, Iran, are also increasingly making their presence in IOR. The non-state actors are also pursing to take the advantage of the volatile environment. But the most far reaching consequence is observed from the recent actions by US. President Trump's recent protectionist approach and unilateral actions defying the international consensus has fueled mistrust about US's commitment of openness and freedom. Therefore, such power struggle among regional and extra regional powers are likely to create more vacuum for confrontation, and thereby, small states like Bangladesh will be the most affected.

Specifically, US's desires to check China's maritime ascendency by establishing a military foothold using Bangladesh's soil, and her skepticism about possible terrorist attacks. Acceptance of such offer is likely to risk her relation with regional powers while re occurrence of terrorist attack may tarnish the image of the country. Secondly, China's increasing ambition through BRI. There are concerns about China's such ambition as there are risk of debt trap. Moving on to trade and economy, there are huge trade deficits and delay in project implementation with projects from both China and India. Thirdly, the US -China trade war raised questions what if President Trump imposes blanket tariff on the export products of Bangladesh? Such actions will be devastating to Bangladesh's economy.

Meanwhile, in security domain there is an ongoing 'Security Dilemma' for the policy makers of Bangladesh. On the regional level, some organizations have not been able to live up to its mandate. Other non- traditional security threats and natural disasters remain ever present, despite mitigation efforts taken by the government. Therefore, if the above-mentioned security concerns are not properly addressed, then it might severely affect the national security of the country.

Bangladesh can get through these difficult challenges by developing appropriate strategy. For this, Bangladesh need to delicately balance her relationships and should not declare her foreign policy against any major power. She should continue to pursue multilateralism in a comprehensive manner and widen her connectivity across the world. On trade and economic front, she should take necessary steps to mitigate the challenges and deficits. Then, Bangladesh needs to have its own military capability to defend her national sovereignty without looking at any one's mercy. Most importantly, government has to address all threats in an integrated and comprehensive manner that will increase effectiveness of security in all sectors while contribute to regional security.

\section{BIBLIOGRAPHY}

1. Ahasan, N. (2018, July 14). What does the US-China trade war mean for Bangladesh? Retrieved July 22, 2018, from The Daily Star: https://www.thedailystar.net/opinion/more-just-facts/what-does-the-us-china-tradewar-mean-bangladesh-1604986

2. Alam, I. (2014, March- May). Indian Ocean: A Vast Potential Frontier For Bangladesh. Foreign Affairs Insights \& Reviews, p 3.

3. Alam, M. (2018, February). How the Rohingya crisis is affecting Bangladesh - and why it matters. Retrieved July 21, 2018, from The Washington post: https://www.washingtonpost.com/news/monkey-

\footnotetext{
${ }^{5}$ The opinion was floated by Pakistan's Army Chief General Qamar Javed Bajwa during his lecture at Malaysian Armed Forces Staff College in April 2018.
} 
cage/wp/2018/02/12/how-the-rohingya-crisis-is-affecting-bangladesh-and-why-itmatters/?utm_term=.e604caf88e41

4. Arman, T. U. (2015, March 25). US strategic interests in \& prospects for Bangladesh. Retrieved July 21, 2018, from Foreign Affairs Insights \& Reviews: http://fairbd.net/us-strategic-interests-in-prospects-forbangladesh/

5. Baylis, J., Smith, S., \& Owens, P. (2017). The Globalization of World Politics: An Introduction to International Relations. (s. edition, Ed.) Oxford: Oxford University Press.

6. bbc.com. (2018, June 15). Trade wars, Trump tariffs and protectionism explained. Retrieved july 14, 2018, from BBC news: https://www.bbc.com/news/world-43512098

7. bdnews24.com. (2018, Jun 14). Retrieved July 28 , 2018, from Japan signs $\$ 1.8 \mathrm{bn}$ to fund six Bangladesh projects in largest loan deal: https://bdnews24.com/bangladesh/2018/06/14/japan-signs-1.8bn-to-fundsix-bangladesh-projects-in-largest-loan-deal

8. Brewester, D. (2015). An Indian Ocean Dilemma: Sino-Indian Rivalry and China's Strategic Vulnerability in the Indian Ocean. Journal of the Indian Ocean , 13.

9. Brewster, D. (2018, Feb 21). The Diplomat . Retrieved june 25 2018, from Welcome to the New Indian Ocean: https://thediplomat.com/2018/02/welcome-to-the-new-indian-ocean/

10. Carafano, J. J. (2018, Feb 3). The National Interest. Retrieved July 29, 2018, from How Bangladesh Can Improve Indian Ocean Security: https://nationalinterest.org/feature/how-bangladesh-can-improve-indianocean-security-24343?page $=0 \% 2 \mathrm{C} 1$

11. Cookson, F., \& Joehnk, T. F. (2018, April 11). China and India's geopolitical tug of war for Bangladesh. Retrieved July 21, 2018, from East Asia Forum: http://www.eastasiaforum.org/2018/04/11/china-and-indiasgeopolitical-tug-of-war-for-bangladesh/

12. Falak, J. (2017, June 21). Implacable Failures of the SAARC. Retrieved July 21, 2018, from Centre for Strategy and Contemporary Research2017: https://cscr.pk/explore/themes/politics-governance/implacable-failuresof-the-saarc/

13. Fernando, S. (2015). USA-China-India Strategic Triangle in the Indian Ocean Region: Challenges and Opportunities. New Delhi: KW Publishers Pvt Ltd.

14. Grevatt, J. (2018, Jun 12). IHS Janes defence weekly. Retrieved July 29, 2018, from bangladesh announces USD 3.45 billion defence budget: http://www.janes.com/article/80793/bangladesh-announces-usd3-45billion-defence-budget

15. Gurung, S. K. (2018, Feb 1). The Economic Times. Retrieved July 28, 2018, from Budget 2018: Defence sector gets a boost by 7.81\%: https://economictimes.indiatimes.com/news/defence/budget-2018-defence-sectorgets-a-boost-by-7-81/articleshow/62746419.cms

16. Hafeez, Q. t. (2017, Sep 14). India's naval expansion plans: Prospects for Pakistan. Retrieved Jun 29, 2018, from foreignpolicynews: http://foreignpolicynews.org/2017/09/14/indias-naval-expansion-plansprospects-pakistan/

17. Hemmings, J. (2018, March 9). The myth of Chinese containment. Retrieved July 14, 2018, from The Interpreter: https://www.lowyinstitute.org/the-interpreter/myth-chinese-containment 
18. Inman, P. (2018, May 9). Why are oil prices soaring as US exits Iran nuclear deal? Retrieved July 14, 2018, from The Guardian: https://www.theguardian.com/business/2018/may/09/why-are-oil-prices-soaring-asus-exits-iran-nuclear-deal

19. Jaysankar, D. (2016, Sep 12). Indian Ocean region: A pivot for Indian's Growth. Retrieved June 25, 2018, from Brookings: https://www.brookings.edu/opinions/indian-ocean-region-a-pivot-for-indias-growth/

20. Kabir, H. (2017, Oct 25). The Financial Express. Retrieved July 28, 2018, from Japan hikes lending rate for Bangladesh:https://thefinancialexpress.com.bd/economy/japan-hikes-lending-rate-for-bangladesh1503998322

21. Kao, J., Crooks, E., \& Pong, J. (2018, July 11). What's at stake in US-China trade war: the full list. Retrieved July 14, 2018, from Finanalcial Times: https://ig.ft.com/us-china-tariffs/

22. Khin, T. (2018, June 15). The Diplomat. Retrieved July 29, 2018, from Why the UN Deal With Myanmar Ignores Rohingya Realities: https://thediplomat.com/2018/06/why-the-un-deal-with-myanmar-ignores-rohingyarealities/

23. Lee, J. Y. (2017). Hedging Strategies of the Middle Powers in East Asian Security: the Cases of South Korea and Malaysia. Springer Netherlands.

24. Michel, D., \& Sticklor, R. (2012). Indian Ocean Rising: Maritime Security and Policy Challenges. Washington, USA: Stimson.

25. Miller, M. C., \& Gopalaswamy, B. (2016, Nov 5). SAARC Is Dead; Long Live SAARC. Retrieved July 28, 2018, from The Diplomat: https://thediplomat.com/2016/11/saarc-is-dead-long-live-saarc/

26. Mukherjee, T. (2018, Apr 24). China's Maritime Quest in the Indian Ocean: New Delhi's Options. Retrieved Jun 29, 2018, from The Diplomat: https://thediplomat.com/2018/04/chinas-maritime-quest-in-the-indianocean-new-delhis-options/

27. Mushtaq, S. B. (2017, June 27). Qatar-Gulf Crisis: Impact on Bangladesh. Retrieved July 21, 2018, from the Diplomat: https://thediplomat.com/2017/06/qatar-gulf-crisis-impact-on-bangladesh/

28. Mushtaq, S. B. (2018, Jan 9). The Diplomat. Retrieved July 29, 2018, from Bangladesh's Ambitious Military Modernization Drive: https://thediplomat.com/2018/01/bangladeshs-ambitious-military-modernizationdrive/

29. Parameswaran, P. (2017, March 3). The Diplomat. Retrieved July 29, 2018, from What Does Myanmar's New Defense Budget Mean?: https://thediplomat.com/2017/03/what-does-myanmars-new-defense-budgetmean/

30. Parameswaran, P. (2018, Feb 28). The Real Significance of India's MILAN Navy Exercise. Retrieved Jun 29, 2018, from The Diplomat: https://thediplomat.com/2018/02/the-real-significance-of-indias-milan-navyexercise/

31. Pathak, A. (2018, Jan 7). What is India's Act East policy? Retrieved Jun 29, 2018, from Quora: https://www.quora.com/What-is-Indias-Act-East-policy

32. Prabandari, A., \& Tobing, D. (2018, Feb 14). Quartz India. Retrieved july 29, 2018, from The challenges of repatriating the Rohingya: https://qz.com/1206879/bangladeshs-rohingya-repatriation-deal-withmyanmar-is-messier-than-it-looks/ 
33. Quora. (2018, may 2). Retrieved July 29, 2018, from What percentage of the budget does the Pakistan military spend and is it at all open for debate?: https://www.quora.com/What-percentage-of-the-budget-does-thePakistan-military-spend-and-is-it-at-all-open-for-debate

34. Rajagopalan, R. P. (2018, Jan 26). ASEAN-India Convergence: The Geostrategic Realities. Retrieved Jun 29, 2018, from The Diplomat: https://thediplomat.com/2018/01/asean-india-convergence-the-geostrategicrealities/

35. Samanta, P. D. (2018, Jan 18). The Print. Retrieved July 28, 2018, from Blow to Beijing: Bangladesh blacklists Chinese infrastructure firm: https://theprint.in/governance/blow-beijing-bangladesh-blacklists-chineseinfrastructure-firm/30289/

36. Scott, M., \& Sam, C. (2018, May 24). Here's How Fast China's Economy is Catching Up to the U.S. Retrieved Jul 13, 2018, from Bloomberg.com: https://www.bloomberg.com/graphics/2016-us-vs-china-economy/

37. Siddique, M. K. (2015, August 26). Increasing Our Maritime Awareness. Retrieved from The daily star: http://www.thedailystar.net/op-ed/politics/increasing-our-maritime-awareness-132394

38. Singh, S. (2017, Mar 3). IORA summit: Can the meet turn a low-profile group into dynamic regional organisation? Retrieved July 21, 2018, from First post: https://www.firstpost.com/world/iora-summit-canthe-meet-turn-a-low-profile-group-into-dynamic-regional-organisation-3313918.html

39. Smith, R. (2018, Jun 13). medium . Retrieved July 28, 2018, from 2018-2019 Defence Budget of India, Pakistan, Bangladesh and Myanmar: https://medium.com/@skunkworksLH/2018-2019-defence-budget-ofindia-pakistan-bangladesh-and-myanmar-d76b4ed250a2

40. Solomon, F. (2017, November 23). Myanmar's Crisis, Bangladesh's Burden: Among the Rohingya Refugees Waiting for a Miracle. Retrieved July 21, 2018, from time.com: http://time.com/5031342/bangladeshmyanmar-rohingya-refugee-crisis/

41. Stashwick, S. (2018, May 11). China's Security Gambit in the Indian Ocean. Retrieved Jun 29, 2018, from The Diplomat: https://thediplomat.com/2018/05/chinas-security-gambit-in-the-indian-ocean/

42. Yamada, G., \& Palma, S. (2018, March 28). Is China's Belt and Road working? A progress report from eight countries. Retrieved July 22, 2018, from Nikkei Asian Review: https://asia.nikkei.com/Spotlight/CoverStory/ls-China-s-Belt-and-Road-working-A-progress-report-from-eight-countries

43. Yueh, L. (2018, Apr 5). https://ig.ft.com/us-china-tariffs/. Retrieved July 14, 2018, from Tehe Guardian: https://www.theguardian.com/commentisfree/2018/apr/05/us-china-trade-war-supply-chains-consumers 